\title{
FREEDOMM AND REHABILITATION IN PAROLE REVOCATION HEARINGS
}

A FEDERAL convict, after serving part of his sentence in prison, may apply for a hearing with a member of the United States Board of Parole to secure his return to the outside world. ${ }^{1}$ If parole is granted and he is allowed to leave prison, the convict is informed that he must report periodically to a designated supervisor-the "parole officer"2 - and is given a list of rules of conduct commonly known as "conditions." 3 These conditions are frequently standardized," including such items as confinement to a particular jurisdiction, maintenance of continuous employment, and avoidance of excessive use of alcohol; at times they may be tailored to the needs of a particular case. ${ }^{b}$ During the parole period, the officer will keep in contact with the parolee by direct observation, personal interviews, and information he may receive from others in the parolee's new environment. After the passage of time, a convict may be discharged from parole to return to the status of an ordinary citizen. But in certain cases the officer may recommend in a report to the Board that the convict be returned to prison because he has "violated" his parole. ${ }^{6}$ If the Board decides that a revocation of parole may be warranted, it must then afford the convict a hearing in accordance with a federal statute which commands that the convict "shall be given an opportunity to appear before the Board..." At this revocation hearing, does the parolee have the right to compulsory subpoena of witnesses? Must the Board appoint counsel if he is indigent? Has the parolee the right to confront and cross-examine all adverse witnesses? Can the hearings permissibly be held at the federal prison from which the convict was paroled if that prison is far removed from the parole locale? These are the questions currently facing federal courts ${ }^{8}$ as they try to give content to the requirement of "an opportunity to appear."

Courts seeking answers to these questions face the problem of whether to continue the modern trend incorporating into the revocation hearing those procedural elements that may be regarded as "trial-type" apparatus. This

1. 1960-61 U.S. Bd. of Parole ANw. Rep. 3.

2. 1961 Rules of U.S. Bd. of Parole 19.

3. Id. at 3. Although a parolee is also released on condition that he not commit further crimes, the Note will use the terms "conditions" and "violation of conditions" to refer to the special restrictions imposed upon the convict during his parole.

4. Modez. Penal Code $\$ 305.17$, comment (Tent. Draft No. 5, 1956).

Although a proposed official draft has been published, this Note will refer to the tentative draft, since the official draft incorporates the tentative draft comments.

5. Ibid.

6. 1960-61 U.S. Bd. of Parole ANN. Rep. 16.

7. 18 U.S.C. $\$ 4207$ (1958).

8. The following five cases raising these questions are pending before the D.C. Circtit : Hyser v. Reed, \# 16716; Jatoft v. Chappell, \# 16806; Whitling v. Reed, \# 16811; 'Thompson v. Parole Board, \# 16873; Kotera v. Chappell, \# 16930. 
trend began in 1946 when the D.C. Court of Appeals in Fleming v. Tate ${ }^{0}$ fully endorsed ${ }^{10}$ the reasoning and holding of the trial court ${ }^{11}$ which found that the District of Columbia parole statute ${ }^{12}$ gives the parolee the right to appear with his retained counsel. The trial court reasoned that "an opportunity to appear ... necessarily contemplates an effective appearance and not the mere physical presence of the prisoner before the Board."13 Although Congress amended the D.C. Code to embody the Tate decision as to counsel ${ }^{14}$ and failed to amend the U.S. Code, ${ }^{15}$ governing all federal parolees, the D.C. Circuit has continued to read the similarly worded federal statute in the light of Tate. ${ }^{10}$ Further holdings that the Board must inform the alleged violator that he may hire counsel, ${ }^{17}$ and that voluntary witnesses must be permitted ${ }^{18}$ have given further impetus to the trend ${ }^{19}$ toward incorporation of trial-type apparatus.

If courts continue their almost uniform denial that the parolee's rights have any constitutional basis, ${ }^{20}$ decisions on whether "an opportunity to appear" includes or excludes particular trial-type procedures should be based upon the purposes of the revocation hearing, since it is only reasonable to assume that in providing for a hearing Congress intended to fit it with a purposeful structure. Such an attempt to correlate the structure of the hearing with the function of parole revocation is suggested in the opinion of Mr. Justice Cardozo in Escoe v. Zerbst, ${ }^{21}$ which is responsible both for the dictum which has been highly influential ${ }^{22}$ in denying that the Constitution guarantees parolees a right to an effective hearing, and for the rationale used by the Tate court $^{23}$ to justify its

9. 156 F.2d 848 (D.C. Cir. 1946).

10. Id. at 851 .

11. In re Tate, 63 F. Supp. 961 (D.D.C. 1946).

12. Indeterminate Sentence and Parole Act of the District of Columbin $\S 5,54$ Stat. 242 (1940), as amended, $\S \S 3,5,6,61$ Stat. 378 (1947), as amended, D.C. Copz $\S 24206$ (1961).

13. In re Tate, 63 F. Supp. 961,962 (D.D.C. 1946).

14. Act of July 17, 1947, ch. 263, § 5, 61 Stat. 378, amending D.C. CoDE $\$ 24-206$ (1951).

15. See Note, 108 U. PA. L. REv. $423,431 \mathrm{n.58}$ (1960) for an analysis of the legislative history.

16. See, e.g., Robbins v. Reed, 269 F.2d 242, 244 n.2 (D.C. Cir. 1959).

17. Moore v. Reid, 246 F.2d 654 (D.C. Cir. 1957).

18. Reed v. Butterworth, 297 F.2d 776 (D.C. Cir. 1961).

19. Although agreement among all the circuits had not been reached, c.g. Washington v. Hagan, 287 F.2d 332, 334 (3d Cir. 1960), the issues of retained counsel and voluntary witnesses are now moot since the U.S. Board has changed its rules to allow both at revocation hearings. 1960-61 U.S. Bd. of Parole ANN. REP. 21, 22.

20. But see Fleenor v. Hammond, 116 F.2d 982 (6th Cir. 1941). See also Note, Lcgal Aspects of Probation Revocation, 59 Colvar. L. Rev. 311 (1959); Comment, Revocation of Conditional Liberty-Califorria and the Federal Systen, 28 So. CAL. I. REv. 158 (1955). 21. 295 U.S. 490 (1935).

22. Washington v. Hagan, 287 F.2d 332, 333 (3d Cir. 1960); United States ex rel. Harris v. Ragen, 177 F.2d 303, 304 (7th Cir. 1949) ; Martin v. United States Bd. of Parole, 199 F. Supp. 542, 543 (D.D.C. 1961) ; Martin v. Warden, 182 F. Supp. 391,393 (D. Mrd. 1960) ; Note, Parole Revocation Procedures, 65. HARv. L. REv. 309 (1951).

23. The lower court in Tate quoted almost half the opinion. Iit re Tate, 63 F. Supp. 962, 963 (D.D.C. 1946). 
conclusion that the particular right to appear with retained counsel was within the ambit of the revocation statute. Construing a probation statute ${ }^{24}$ similar in relevant part to the federal parole statute, ${ }^{25} \mathrm{Mr}$. Justice Cardozo reasoned that:

Clearly the end and aim of an appearance before the court must be to enable an accused probationer to explain away the accusation. ... This does not mean that he may insist upon a trial in any strict or formal sense. . . . It does mean that there shall be an inquiry so fitted in its range to the needs of the occasion as to justify the conclusion that discretion has not been abused by the failure of the inquisitor to carry the probe deeper,

If the "needs of the occasion" determine the extent of the "opportunity to appear" some clear view of the dominant aim ${ }^{27}$ of revocation is required before the procedural needs of the hearing can be ascertained. And, since a decision to revoke must be regarded as a decision that desired goals would no longer be served by continuing parole in a particular case, the first question courts should ask in their search for the purpose of revocation hearing is: What are the aims of parole?

At least two distinct dominant aims of parole are plausible, with very different implications for the procedural requirements of parole revocation hearings. It may be that parole is a device for removing people from prison after it has served its protective, punitive, and deterrent function simply because it is assumed that extended stays in prison have debilitating effects. Under this view no judgments are made about the quality of treatment the parolee will receive on the outside. Such a view might well be adopted because it is believed that our present ability to predict and affect future behavior through treatment is limited. But the real impetus behind this view would seem to come from a desire to decrease deprivations of freedom and increase the opportunity for self-direction. Hence such a view may envision maximum freedom as the dominant aim of parole. But although increased freedom is the conspicuous feature of parole, rehabilitation of the convict in a manner consistent with public safety is most frequently articulated as its dominant aim. ${ }^{28}$ Such articulations rarely define

24. Act of March 4, 1925, ch. 521, $\$ 2,43$ Stat. 1260 (“. . such probationer shall forthwith be taken before the court. ...").

25. 18 U.S.C. $\S 4207$ (1958) ("... shall be given an opportunity to appear before the Board....").

26. Esçoe v. Zerbst, 295 U.S. 490, 493 (1935).

27. A parole system designed to fulfill a "dominant aim" might well accommodate a variety of subsidiary aims, but one is "dominant" in the sense that it takes precedence over other aims whenever a conflict arises.

28. See, e.g., Address by George J. Reed (Member, U.S. Board of Parole), National Institute on Crime and Delinquency, July 23, 1962; Fleming v. Tate, 156 F.2d 848, 850 (D.C. Cir. 1946) ; Goergen v. State, 196 N.Y.S.2d 455, 457 (Ct. Cl. 1959) ; Brief for Appellees, p. 14, Hyser v. Reed, \# 16716 (D.C. Cir. 1962); Report of the Commillec Appointed to Inquire into the Principles and Practices Followed in the Remission Scrvice of the Department of Justice of Canada, 51 (1956) ; 2 U.S. Code CoNG. \& AD. NEWs 3896, 3904 (1958). National Conference on Parole, Parole in Principle and Practice 66 (1957). 
this aim, but rehabilitation must involve a reduction of the likelihood that the subject will commit further crimes when the convict returns to the status of an ordinary citizen. Under this view, however, parole may represent an active program of rehabilitation which permits experts to engage in assessing which environment under what conditions is most likely to increase the probability of voluntary compliance with law. Just as the divorce law permits modification of the custody of a child when there has been a "change of circumstances" warranting such a modification "in the best interests of the child,"20 so parole and revocation of parole may be devices for changing a convict's environment when experts deem it to be in his best interest. With such a rehabilitative goal, the role of the parole administrators would be one of continued surveillance, analysis and prediction concerning the convict, his environment, and the likelihood that the ultimate goals of rehabilitation will be achieved. If the procedural needs of a revocation hearing are to be fitted to the aims of parole, an examination of the implications of these two different views of parole would seem to be a prerequisite for courts seeking to give content to "an opportunity to appear." For the adoption or rejection of any particular procedural element should depend on whether it furthers or undermines the dominant aim of parole.

If maximum rehabilitation consistent with public safety is the dominant aim of parole, then questions like the following must be answered in determining whether continued parole is appropriate:

How likely is it that the convict will be helped on the outside? How much will he be helped ?30

How likely is it that the convict will be dangerous on the outside? How dangerous? ?31

How likely is it that the convict will be helped on the inside? How much will he be helped ?32

Because a rehabilitatively oriented revocation hearing demands some such line of inquiry, ${ }^{33}$ a rationale may be provided for the distinction frequently

29. 27B C.J.S. Divorce $\$ 322(2)$ (1959).

30. The Board may have paroled a homosexual in the hope that he would use his recent large inheritance to avail himself of psychiatric help. If he gambled large amounts away, or if large amounts were stolen, such facts might be relevant in answering this question.

31. This question may go to which law he is likely to violate. Presumably a tendency to commit crimes against the person would weigh more than crimes against property. But quaere: If the prisoner was convicted for income tax evasion, should the Board also consider the likelihood that he will commit murder on parole? Does conviction for one act authorize invocation of the state's rehabilitative apparatus for all purposes?

32. The questions of likelihood and magnitude of danger on the inside would probably not be important ones, since in most cases such problems could be alleviated by reincarceration under special security measures or at another prison.

33. Under a rehabilitative theory the revocation hearing differs from the original parole hearing only by a time factor. The questions are the same. One might view the two hearings as held in a room with a door at each end, one leading to prison and the other to the outside world. Where the convict was before he entered the room is relevant but not controlling. This similarity in the hearings should be taken into account when consideration is given to the problem of safeguards at the original parole hearing, a problem which may 
drawn between the nature of this hearing and that of a trial. ${ }^{34} \mathrm{~A}$ trial is designed to establish only a past event. The revocation hearing is designed to organize a total image of an individual's situation. The trial determines what happened; the hearing predicts what is likely to happen. Past facts-such as whether the parolee has violated a condition of his parole-are of course relevant to such a revocation hearing, but only insofar as they shed light upon the ultimate issue of what the parolee is likely to do after the hearing. It may be for this reason that decisions to revoke are frequently made only after several violations are observed..$^{35}$ Courts have been in uniform agreement that an "i11formal" hearing is best suited to the task of making these decisions. ${ }^{20}$ But the argument for "informality" cannot rest on the difference between the way facts are used at the hearing and at the trial. It is true that the establishment of $a$ single past fact at a hearing is not necessarily dispositive of the revocation decision, since the prediction of a man's behavior cannot, at present, depend solely on a mechanical appraisal of a number of past facts. But the prediction of a future fact still depends, in large part, on a thorough gathering of facts from past and present, even if ultimately these facts must be mingled with elements of intuition, professional and otherwise. Thus, although the revoctu tion decision oriented toward rehabilitation may not be based solely on ascertained past facts, unless it can be shown that the hearing itself has other than fact-finding functions which formal trial procedures would impede or that the implementation of these procedures would conflict with the goals of the system, there is no apparent reason why the hearing should not take advantage of the full fact-finding pressure of the trial-type adversary process..$^{37}$

The implicit rationale of the D.C. Circuit in Fleming v. Tate, ${ }^{\text {s8 }}$ the seminal case in the trend toward incorporation of trial type procedures, ${ }^{30}$ seems well

well arise in the near future. Address by George J. Reed (Member of U.S. Board of Parole), National Institute on Crime and Delinquency, July 23, 1962. Courts in the past have expressly denied extension of their revocation hearing holdings to the original parole hearings. See, e.g., Fleming v. Tate, 156 F.2d 848, 849 (D.C. Cir. 1946).

34. See, e.g., Hock v. Hagan, 190 F. Supp. 749, 751 (M.D. Pa. 1960).

35. 1960-61 U.S. BD. of PAROLE ANN. REP. 16. For a discussion of sanctions short of revocation, see Moder PeNal CodE $\S 305.19$, comment (Tent. Draft No. 5, 1956). But even though boards tend to use "conditions" more as guides than as strict "conditions," the survival of the language of "conditions" has probably had its effect in presenting to the courts the image of the hearing as a kind of trial designed to deal with an alleged fact.

36. See, e.g., Christianson v. Zerbst, 89 F.2d 40, 43 (10th Cir. 1937) ; Hiatt v. Compagna, 178 F.2d 42, 46 (5th Cir. 1949), aff'd without opinion by an equally divided couth, 340 U.S. 880 (1950). Even courts extending parolees' rights in the hearing have supported the view that informality should be maintained. Fleming v. Tate, 156 F.2d 848, 849 (D.C. Cir. 1946) ; United States ex rel. McCreary v. Kenton, 190 F. Supp. 689, 691 (D. Conn. 1960).

37. In the absence of very explicit authorization to the contrary the Supreme Court assumes that Congress intended to outfit a fact-finding adjudicatory hearing with the traditional safeguards of due process. Greene v. McElroy, 360 U.S. 474, 507 (1959).

38. 156 F.2d 848 (D.C. Cir. 1946).

39. See, e.g., Reed v. Butterworth, 297 F.2d 776, 777 (D.C. Cir. 1961); Glenn v. Recd, 289 F.2d 462, 463 (D.C. Cir. 1961) ; Robbins v. Reed, 269 F.2d 242, 243 (D.C. Cír. 1959); Moore v. Reid, 246 F.2d 654, 655, 659 (D.C. Cir. 1957). 
suited to the diagnostic and prognostic functions of a hearing in a parole system whose dominant aim is rehabilitation. When the Tate court decided that the parolee's counsel should be permitted at revocation hearings, it supported its decision with arguments from two vantage points. The court recognized the needs of the parolee in finding that he should be enabled to present fully whatever information he deems pertinent to his case. ${ }^{10}$ Insofar as the goal of rehabilitation is a respect for law and order, the granting to the parolee of what will seem to him a "fair deal" by giving him ample opportunity to present his side of the story will in itself increase that respect. 11 Even more important, however, the court recognized that the interest of the parolee in making a full presentation coincided with the needs of the Board in having the information relevant to the particular determination the hearing is designed to make. 12 When it examines the revocation recommendation of the parole officer the Board is confronted with information which may be direct or the product of confidential disclosure. In order to make an informed prediction the Board will need as thorough a presentation of all facets of the case as it can obtain. The court also added the statement that:

The presence of counsel does not mean that he may take over control of the proceeding .... The presence of counsel and the receipt of testimony offered by the prisoner need not prolong the hearing beyond the time necessary for the Board to ascertain the facts. ... This need be no greater than is necessary to insure to the Board as well as to the prisoner that the Board is accurately informed from the parolee's standpoint before it acts, and the permitted presentation need be no greater than is necessary for the same purpose. ${ }^{43}$

It thereby appeared to recognize that procedural techniques designed to insure full presentation should be incorporated only to the extent that they do not interfere with other demands imposed by the dominant aim of a parole revocation hearing-the establishment of a basis for deciding what is appropriate rehabilitative treatment. Although not considered by the Tate court, the logic of this rationale would also preclude the incorporation of procedural techniques where they seriously undermine the dominant aim of the parole system as a whole.

Not surprisingly, this reasoning supports Tate's holding that the statute should be construed to embrace the right to retained counsel. Presumably a lawyer will be more skilled than the parolee in the presentation of whatever

40. 156 F.2d 848, 850. ". . . the parolee should be enabled to present whatever he may have to present pertinent to the question raised by his alleged act."

41. "An appearance of just dealing is as indispensable as justice itself." In re Tate, 63 F. Supp. 961,963 (D.D.C. 1946).

42. $156 \mathrm{~F} .2 \mathrm{~d}$ at 850 . "Obviously, the Board is to ascertain the facts, and decide what effect should be given them. Its discretion in continuing or revoling parole is uncontrolled, but clearly ... it cannot act in disregard of the facts or refuse to hear argument."

43. Id. at 849,850 . For the purpose of enabling the Board to control lawyer participation effectively and fairly it might be suggested that a lawyer always be among its membership. 
facts are relevant. ${ }^{44} \mathrm{He}$ can explain the nature of the proceedings to the parolee ${ }^{45}$ and clarify misunderstandings arising from the written record. And even if he is not permitted to object to the consideration of information from relatively unreliable sources, since hearsay is permitted, ${ }^{40}$ his characterization of the nature of the evidence may be of use to the Board in determining its probative weight. Since counsel, if restricted, would not interfere with the function of the hearing, and since he can be of positive aid to both the parolee and the Board, an effective "opportunity to appear" should mean to appear with retained counsel.

Although the opinion of the court in Tate contains express dictum to the contrary, ${ }^{47}$ the reasoning which supports the allowance of parolee's counsel also demands appointment of counsel for the indigent. If an "opportunity to appear" means an effective opportunity, and effectiveness is geared to the concept of adequate presentation of the case, it would be unreasonable to hold that the standard of effectiveness is dependent upon the affluence of the parolee. Since neither the needs of the Board nor those of the convict vary an iota when an indigent parolee is involved, the Escoe-Tate rationale, consistently applied, demands the same decision as to counsel in his case. ${ }^{48}$

44. For discussion of the role of counsel see Kadish, The Advocate and the ExpertCounsel in the Peno-Correctional Process, 45 Mrns. L. Rev. 803 (1961); Tappan, Thic Role of Counsel in Parole Matters, Practical Lawyer, Feb. 1957, p. 21.

45. For an elaboration of an instance in which just such legal help was needed, sec Moore v. Reid, 246 F.2d 654 (D.C. Cir. 1957).

46. See Christianson v. Zerbst, 89 F.2d 40, 43 (10th Cir. 1937). Fleming v. Talc extended the privilege of introducing hearsay evidence to the prisoner. 156 F.2d 848, 849 .

47. 156 F.2d 848, 849. Judge Holtzoff, the lower court judge in Tatc, recently converted that dictum into a holding in Martin v. United States Bd. of Parole, 199 F. Supp. 542 (D.D.C. 1961).

48. Indeed, such a holding may be compelled by recent cases construing the equal protection clause. "There can be no equal justice where the kind of trial a man gets depends on the amount of money he has." Griffin v. Illinois, 351 U.S. 12, 19 (1956) (denial of equal protection for state to refuse to give free trial transcript to indigent defendant so that lic might prosecute on appeal). See also Burns v. Ohio, 360 U.S. 252 (1959); Smith va Bentnett, 365 U.S. 708 (1961).

Although the equal protection clause does not apply directly to the federal government, "discrimination may be so unjustifiable as to be violative of due process." Bolling v. Sharpe, 347 U.S. 497, 499 (1954). The Court has indicated that the federal government cannot constitutionally distinguish between indigent and nonindigent defendants. See Coppedge v. United States, 369 U.S. 438 (1962).

The Tate court's distinction between the right to retained counsel and the right to appointed counsel may have had its basis in a similar distinction drawn in connection with the demands made by the fourteenth amendment's due process clause upon state criminal procedure. A nonindigent defendant has an absolute right to retained counsel in a state criminal proceeding. Chandler v. Fretag, 348 U.S. 3 (1954). However, an indigent has a right to appointed counsel in a state noncapital case only upon a showing of "special circumstances." Betts v. Brady, 316 U.S. 455 (1942). But even if the Betts rule remains part of our law, it should be noted that the Tate court was operating in a federal context. In federal criminal trials there is an absolute right to both retained and appointed counscl. 
But Tate's dicta did not stop at the assertion that there is no right to appointed counsel. The court went on to suggest that no other procedural safeguards would be required in the revocation hearing, since their inclusion would convert the hearing into a "legal battle." right to compulsory subpoena, seems inconsistent with the needs of a revocation hearing in a system whose dominant aim is maximum rehabilitation. For participation by witnesses would further the goal of adequate presentation without unreasonably encumbering the Board. Testimony, like participation of counsel, could be confined to relevant matters so as to insure the Board's continuing control over the hearing.

However, this dictum, in impliedly denying the right to confront and crossexamine adverse witnesses, would be consistent with the implicit rationale of the Tate decision. For the right to confront and cross-examine adverse witnesses would seriously weaken the effective operation of a parole system oriented toward rehabilitation while affording relatively minor gains. It is true that both the parolee and the Board would benefit from the expanded record that crossexamination would produce. The parolee would be provided with an increased opportunity to explain, more adequately characterize, and test the veracity of, some aspects of the case against his continued liberty. But, unlike the trial, where one crucial event is in issue, the revocation hearing is designed to get at the numerous facts bearing on the balance of help and danger in two environments. The right to confront and cross-examine all adverse witnesses would require that the Board disclose all the sources of its information. Such disclosure would tend to impede the flow from sources that might be most relevant to the ultimate decision and vital to the health of parole's rehabilitative apparatus. Because the number of parole officers is limited and the kind of behavior which may justify revocation is frequently ordinary conduct for the man-in-the-street and hence unlikely to come to the attention of police officers, the system depends on information being supplied by those specially acquainted with the parolee. The parole officer's report is thus likely to be a mixture of direct observation and accumulated hearsay. Reports from employers who have demonstrated a willingness to hire parolees, for example, may be of great assistance to the decision. But to force such employers to attend hearings not only would render them less likely to continue to contribute to the rehabilitative effort, but also would involve the risk of news of their testimony leaking back through the prison grapevine. Thus this source of rehabilitative employment might well be lost.

Further, since the hearing is the Board's sole opportunity to confront and observe the parolee directly, it is desirable to limit the number of participants. While it may be argued that this reasoning would also justify the elimination of the parolee's witnesses, the need for facts that might be otherwise unavailable to the Board argues otherwise. Since a parole officer's time is unavoidably limited, the bulk of his concern is with negative aspects of the parolee's be-

49. 156 F.2d 848,849 (1946). 
havior. Neither the parole officer nor the Board has a prosecutorial interest in revocation $;^{50}$ hence both want to check on the veracity of such reports. But since the presentation of the positive aspects of his behavior is largely left to the parolee, who does have an advocate's interest in the outcome of the proceeding, the presence of the parolee's witnesses, in addition to serving the function of full presentation, provides the Board with its only opportunity to make the same veracity check on positive reports that it presumably has already made on negative reports. Thus, it would appear that although the goal of rehabilitation is furthered by as complete a record as possible, not to allow confrontation and cross-examination of all adverse witnesses is not to sacrifice rehabilitative goals, but to maximize them. For preservation of rehabilitative opportunities, sources of predictive information, and the suitability of the hearing as a forum for personal evaluation outweighs the gains both to the Board and the parolee to be derived from carrying the probe deeper.

If "an opportunity to appear" is read to include the procedural elements recommended above, there would be no compelling reason for requiring that the Board abandon its policy of holding revocation hearings at the federal prison from which the convict was paroled, even though that prison is frequently far removed from the parole locale. ${ }^{51}$ The problem of access to witnesses would be solved by use of the compulsory subpoena. Access to the actual "scene of the crime" is seldom crucial because, in a system whose dominant aim is rehabilitative treatment, the nature of one given event is rarely the pivotal issue. Notwithstanding this, in the interest both of increasing its fact-finding efficiency and of furthering its image of neutrality before the courts and parolees, the Board should abandon this practice on its own in favor of henrings held at the federal prison nearest the parole locale. By reducing the nutmber of witnesses who cannot volunteer to take the frequently lengthy trip to the hearing, this change would reduce the use of compulsory subpoena. Furthermore, it would not only increase the parolee's opportunity to have a lawyer with whom he is familiar, but it would increase the possibility that the lawyer would have the kind of knowledge of the particular man and his environment most useful to the Board. Since the Board already makes annual visits to every

50. To the extent that parole boards are motivated by a desire to avoid bad publicity, by a desire for retribution against those parolees who have "let them down," or by a desire to back up the parole officer, their neutrality may be called into question. Proposals designed to make parole officers responsible to an authority other than the Board itself may be designed to diminish prosecutorial pressures in the system. See generally MODEL PENAL CoDE art. 401, comment (Tent. Draft No. 5, 1956). The relationship between the Board and the Parole Executive may be of crucial significance in this regard. See text at note 77 infra.

51. Incorporation of the suggested safeguards would tend to achieve in terms of space what the court in United States ex rel. Buono v. Kenton, 287 F.2d 534 (2d Cir. 1961) sought to achieve in terms of time when it held that an unreasonable delay would invalidate a hearing. "A long delay in time makes it less likely that sources of evidence which the prisoner may ask the Parole Board to consider will be available." Id. at 536. 
federal prison, ${ }^{52}$ such a change in its rules would not be disruptive of its activities.

The foregoing construction of "an opportunity to appear" is based upon the assumption that Congress intended maximum rehabilitative treatment consistent with the public safety to be the dominant aim of parole. ${ }^{53}$ But there are other features of the system of parole established by Congress which suggest that although rehabilitation may be a significant aim of parole, it is not the dominant aim. The statutory provision that time served on parole does not count toward the sentence ${ }^{54}$ might be taken to belie the notion that recommitment is simply a change in a convict's environment for rehabilitative purposes

52. 1960-61 U.S. BD. of Parole ANN. Rep. 40-41.

53. Proponents of the view that introduction of rehabilitative aims into the law leads to tyranny perpetrated in the name of humanitarianism have been numerous. See, e.g., Dostoevsky, Notes from tHe Underground aNd The Grand Irouisitor (Alatlaw trans. 1960), and THe PosSEsSEd (Garnett trans. 1936). See also C. S. Lewis, The Humanilarion Theory of Putishnnent, reprinted in Donneliy, Goldstern \& Scrwartz, Crnomins Law: Problems for Dectsion in the Pronsulgation, Invocation and Adarinistration of a LAW OF CRRES 499 (1961). This view may mean that malevolent practices will be disguised beneath a cloak of kindness. Or it may mean that even if ideal benevolence is operant, whenever a conflict arises between individual freedom and the needs of the state's treatment agents, the logic of rehabilitative theory will demand that the state's needs prevail. The conclusions of the first part of this Note may lend weight to this latter viev insolar as they suggest that only those "safeguards" should be incorporated in the revocation hearing which further the aims of rehabilitation. Thus, though the suggested procedures may function as "safeguards" against malevolent practices, they do not function as "safeguards" against benevolent rehabilitative tyranny.

54. 18 U.S.C. \& 4205 (1958). Since a returned violator gets no credit for time served on parole up to the point of violation, his sentence is in effect increased. This practice would seem to undermine the argument that because a revocation hearing is not a "criminal prosecution" parolees are not entitled to sixth amendment rights. But see $108 \mathrm{U}$. PA. L. REv. 423, 426 (1960).

55. The practice mentioned in note 54 supra could, in the extreme, serve the ends of a malevolent tyranny perpetrated in the name of treatment, since a prisoner could be let out for long periods and returned for short stays, thereby serving his sentence piecemeal over many years. Used in such a fashion, parole could become a device for maintaining state control over those deemed "troublesome." At one point Illinois appeared to acknowledge just that function. "Its purpose [the parole law of 1895] was, and the result has been, to give the state greater and more prolonged control over every person who should hercafter be sentenced and committed to a penal institution." State of Irsmors, Dept. of Punlic Welfare, Illmois Parole Law-Accosmplisharents, Statistical Data, Papers and Addresses on Its Provistons and Its Adarinistration 19 (1921). New York does give credit for time served on parole up to the point of violation. People ex rel. Dote v. Arartin, 294 N.Y. 330, 62 N.E.2d 217 (1945). But in federal cases, for the purpose of denying parolees' rights, parole is viewed as merely "'an extention of the prison valls;' and the prisoner while on parole remains in the legal custody and under the control of the Parole Board." United States ex rel. Rowe v. Nicholson, 78 F.2d 468, 469 (4th Cir. 1935), cert. dentied, 296 U.S. 573 (1936). Yet for the purpose of counting time courts have urged that "imprisonment contemplated by Federal law is confinement in fact." Howard v. United States, 274 F.2d 100, 103 (8th Cir. 1960), cert. denied, 363 U.S. 832 (1960). The federal statute now requires that, "... the time the prisoner was on parole shall not diminish the time he was sentenced to serve." 18 U.S.C. $\$ 4205$ (1958). 
since it would seem that time served in treatment inside and outside should count equally. Even more important, however, if the question at the heart of a revocation hearing were simply which environment is most likely to facilitate the rehabilitation of the convict with minimum danger to society, it is difficult to understand why the revocation statutes are phrased solely in terms of violation of conditions. ${ }^{68}$ A parole law geared to the rehabilitation needs of the parolee might provide for his recommitment, wholly apart from any positive violation on his part, when there has been a change in his circumstances-such as the death of his family-which seriously diminishes the possibility of help in the outside world. ${ }^{57}$ But the statutes do not expressly provide for recommitment where there has been a change in circumstances. And in fact, courts have held that some evidence of violation is required for a valid revocation decision. ${ }^{\text {t8 }}$ Although the parole statutes do not expressly require that a condition be violated before a revocation may issue, ${ }^{60}$ comparison of these statutes with the mandatory release statute ${ }^{60}$ strongly indicates that the language of "violation" is not inadvertant, and thus that a parole revocation scheme geared to violation of conditions was envisioned. Until 1951, Congress provided that mandatory releasees ${ }^{61}$ are to be treated "as if on parole and shall be subject to all provisions of law relating to the parole of United States prisoners." 62 The mandatory release statute, in part designed to discourage infraction of prison rules, appears to presume that the hastening of the increased freedom of parole is desirable, even if it could be shown in a particular case that prison offered the better rehabilitative opportunities. Since a demonstrated ability to live without transgressing rules is the sole criterion for mandatory release, it must be presumed that Congress did not intend to provide for the recommitment of releasees while they continue to abide by the conditions of release, even if it could be shown that opportunities for rehabilitation are greater in prison. Thus, if infraction of the conditions of liberty is the sole criterion for recommitment of a releasee, and releasees are subject to "all provisions of law" relating to ordinary parolees, it can be concluded that infraction of conditions must have been an assumed prerequisite to revocation under the ordinary parole law. Although Congress amended the mandatory release statute in 1951 in a way which necessitated the deletion of the phrase "all provisions of law," legislative history strongly supports the view that the amendment involved no major change in the congressional view of parole. ${ }^{63}$

56. 18 U.S.C. $\$ 4205$ (1958); 18 U.S.C. $\$ 4206$ (1958).

57. There is some suggestion that the Board considers treatment efficiency in its revocation decisions in 1960-61 U.S. Bd. of Parole ANN. Rep. 16.

58. See, e.g., United States ex rel. De Lucia v. O'Donovan, 107 F. Supp. 347 (N.D. III. 1952).

59. 18 U.S.C. \& 4207 (1958).

60. 18 U.S.C. § 4163 (1958); 18 U.S.C. $\$ 4164$ (1958).

61. Mandatory release is a term referring to statutory early release "in the absence of parole or pardon." 1961 Rules of U.S. BD. of PAROLE 5n.

62. Act of June 25, 1948, ch. 645, § 4164, 62 Stat. 353.

63. In order to avoid costly short period recommitments, the amendment provides for unconditional release for those with less than 180 days to serve under the maximum sentence. 
Such conspicuous aspects of the system, incompatible with a dominant aim of maximum rehabilitation, are reconcilable if parole is viewed as a device designed to encourage continued rehabilitation but only to the extent that such encouragement is consistent with the dominant aim of maximum freedom. Where maximum freedom is dominant, parole may be looked upon as a method for hastening the return of the convict to society under conditions which protect against further incarceration. These conditions would establish the legal boundaries of the convict's freedom and the limits upon the deprivation of that freedom. That is, the convict may not be returned to prison until he demonstrates a disrespect for the freedom of others by transgressing the special legal bounds of his freedom. Thus, conditions of parole, like ordinary criminal statutes, might be viewed as designed to maximize freedom in the sense that they represent not only the limits upon the extent to which the parolee may infringe upon the freedom of others, but also the limits upon the extent to which the state may infringe upon the freedom of the parolee. ${ }^{\text {at }}$ Under this view, rules maximize liberty by defining the barriers against encroachments upon liberty by both man and society. ${ }^{65} \mathrm{~A}$ criminal law consistently designed for thoroughgoing rehabilitation would not wait for the act, but would authorize investigation and treatment of the "potentially dangerous."00 But a criminal law designed for maximum freedom encourages the free movement of even the most dangerous until the failure to control that dangerousness is manifested in an established act. Since proof of the commission of an act proscribed by the conditions of parole would thus be a prerequisite to revocation, the focus of the parole revocation hearing, like a trial, would be upon establishing a past violation.

It may well be that an appraisal of the current state of human capacities for prediction ${ }^{67}$ and treatment would lead a legislature to select maximum free-

No change is made with respect to those mandatory releasees with more than 180 days leit. The remarks of the Deputy Attorney General that, "We do not think, the proposed change ... involves any change in basic policy," have been included in the Senate Report. S. REP. No. 385, 82d Cong., 1st Sess. 4 (1951).

64. Although requiring respect for conditions of parole in addition to the ordinary criminal laws diminishes the parolee's freedom, protection of the freedom of others requires that reincarceration not be forestalled until he again infringes on society's freedom by committing another crime. Conditions of parole may thus be based on an empirical assumption that a past showing of disrespect for the freedom of others is probative of a present threat. Society then curtails the parolee's freedom in the interest of its own by requiring that he demonstrate an ability to live under lifelike circumstances without transgressing rules. Even though the conduct required to break a condition would not be regarded as sufficient proof of an ordinary citizen's disrespect for the freedom of others, the convict's past inability to abide by the legal bounds of his freedom taken together with a subsequent violation may rationally be so regarded. But in the interest of the parolee's freedom society would demand another positive showing of transgression, not a naked prediction of dangerousness, before it would allow reincarceration.

65. See generally MILI, ON LiBerty (1873).

66. Strictly speaking, "potential dangerousness" is a misnomer since dangerousness itself is a potentiality.

67. See Hayner, Why Do Parole Boards Lag in the Use of Prediction Scoresp, reprinted in Donneliy, Goldstern, \& Schwartz, Cronrinal Law: Problears for Decision 
dom as the goal most likely to further the rehabilitative aims of parole. Unless the expertise required to make subtle rehabilitative assessments of the shifts in the quanta of danger and help is sufficiently refined, and the resources available for treatment are adequate, the convict may be exposed to decisions which border on caprice. ${ }^{68}$ The legislator might reason that the freedom of parole will not only spare the paroled convict the debilitating effects of an overly long stay in a prison ${ }^{69}$ whose rehabilitative apparatus is little more than mythical, but will also permit him, indeed force him, to make responsible decisions in a world where his freedom is restricted only for the purposes of aggregate freedom.

Since the requirement that a condition be violated before parole is revoked suggests the view that maximum freedom, rather than maximum rehabilitation is the dominant aim of parole, the hearing should be designed to answer the question suggested by the statutory language: did the parolee commit a violation? Thus, in the absence of a showing that such safeguards would work to the detriment of the postulated dominant aim, courts should incorporate into the hearing those procedural elements which our system presumes to be best suited to determining the occurrence or nonoccurrence of a past event. This would demand a construction of an "opportunity to appear" to embrace, in addition to the right to counsel and compulsory subpoena of witnesses, the right to confront and cross-examine all adverse witnesses.

Since our adversary system ordinarily assumes that these procedural elements best serve the fact-finding function and since the integrity of that function is paramount in a system whose dominant aim is maximum freedom, there are no detriments to be balanced against the inclusion of any of the above procedural safeguards. Although, as noted previously, confrontation and crossexamination would impede the functioning of rehabilitative aspects of the parole system, ${ }^{70}$ the dominant aim of maximum freedom would nevertheless be served. If maximization of freedom is the dominant aim, the balance of gains and losses to rehabilitative aspects of the treatment program ought no longer to control decisions on the extent of the opportunity to appear.

However, the parole statutes do not uniformly warrant the conclusion that Congress intended a system geared to maximum freedom. The statutory grant of wide "discretion" to the Board ${ }^{71}$ would seem to argue for the view that a treatment oriented program was intended. For the use of the term "discretion" suggests that the proceeding envisioned by Congress was one not readily amenable to effective review. ${ }^{72}$ Broad discretion and limited review is more con-

in the Promulgation, Invocation and Administration of a Law of Chimes 241 (1961). See generally 8 CRIME AND DeLINQuency 209-314 (1962).

68. A recent study calls into question the degree to which professional parole board members are more skilled at making parole predictions than ordinary laymen. Hakcem, Prediction of Parole Outcome from Summaries of Case Histories, 52 J. Cum, L., C. \& P.S. 145 (1961).

69. This line of reasoning appears in S. Rep. No. 2013, 85th Cong., 2d Sess. 4, 5 (1958).

70. See text at note 50 supra.

71. 18 U.S.C. \& 4207 (1958).

72. See generally J. Goldstein, Police Discretion Not to Invoke the Criminal Process: Low-Visibility Decisions in the Administration of Justice, 69 YALE L.J. 543 (1960). 
sistent with a rehabilitative decision involving fine evaluations of the parolee's character and balancing of the quanta of help and danger. An alternative reading of the grant of "discretion" is that Congress did not intend the Board to be wholly tethered by parole's dominant aim-be it rehabilitation, freedom, or something else-but rather wanted to give the Board the opportunity in appropriate cases of tempering the demands of the dominant aim with the implications of other secondary aims. If this be the meaning of discretion, then Congress has not completed its mandate by instructing the Board and the courts what goal is to be dominant and what secondary. If, on the other hand, the grant of discretion be taken to imply that Congress envisioned a treatment oriented system, then again Congress has failed to communicate clearly the dominant aim of parole, for other sections of the statutes, ${ }^{73}$ by talking in terms of parole violation, strongly suggest that maximization of freedom is that aim.

Whatever the dominant aim of parole, judicial attempts to enhance the effectiveness of the federal hearing necessarily must fail unless courts recognize the fact that crucial decisions are made at earlier stages in the revocation process. Although the Tate court acknowledged disapprovingly that in most instances the hearing is merely a formal final check on a decision already largely made when it was decided to hold the hearing, ${ }^{74}$ neither Tate's remedies nor subsequent ones deal with other factors which limit or nullify the effectiveness of an opportunity to appear at the hearing. Because its responsibility extends to all facets of the entire federal parole system, ${ }^{75}$ the Board is unable to read the revocation recommendations from the parole officers. As a result, such recommendations are submitted to the Parole Executive-not a member of the Board-who decides ${ }^{78}$ whether a report merits recommending to the Board that a warrant be issued. Approximately one-half to two-thirds of the 150 monthly violator reports result in such recommendations. ${ }^{77}$ The vast majority of such recommendations result in warrants and, therefore, hearings. The vast majority of such hearings result in revocations. ${ }^{78}$ In the interest of providing an effective hearing at the Board level with the kind of expanded record which the Board lacks the time to develop in its hearings, courts should extend statutory "due process" to include transcribed hearings at the parole officer level, and to require that the Board consider each revocation recommendation report and the record of the hearing. This admittedly extreme construction of an

73. See text at notes 56-62 supra.

74. 156 F.2d 848, 851. The court cited 4 Art'y Gen. Survey of Release Procedures 246,247 (1939).

75. 1960-61 U.S. Bd. of Parole ANN. Rep. 2.

76. In borderline cases, the Parole Executive discusses the matter with the Chairman of the Board. Letter from Joseph N. Shore, Parole Executive, to the Yale Low Joumal, August 16, 1962, on file in Yale Law Library.

77. Ibid. In many instances, the Parole Executive carefully reviews the case prior to the hearing to see if subsequent reports warrant reinstatement on parole rather than a revocation hearing.

78. Ibid. To the extent that it feels a need to back up the Parole Executive, the Board may effectively lose its non-prosecutorial character. 
effective "opportunity to appear before the Board" would probably have the effect of forcing Congress to reexamine the amount of resources allocated to the parole decision-making process. At present, the practical demands made by time ${ }^{79}$ appear to be wholly inconsistent with the statute's intent to create an effective chance to be heard at the federal Board level.

Until Congress clarifies the nature and priority of its purposes, juclicial efforts to convert the revocation hearing into an effective opportunity for both the parolee and the Board will continue to founder among the criteria for decision which follow from the two viable, but conflicting, views of parrole. Were the courts to reverse repeated dicta ${ }^{80}$ and hold parolees to be entitled to hearings which accord with the requirements of constitutional due process, clarification of the goal of parole would be essential to determining what sort of process is "due." 81 But if-as is likely-courts continue to hold that a parolee's rights can derive only from the statutes, continued application of the Escoe-Tate rationale also demands such clarification becatıse an appreciation of the needs of the hearing depends on a clear view of its purposes and the questions which must be asked to fulfill them. When Congress articulates its purposes, it will make clear what it wishes those questions to be. Until then courts should not assume that any of the safeguards ordinarily required when liberty is at stake have been intentionally abandoned. ${ }^{82}$ Whether this result does or does not comport with the present intent of Congress cannot be determined, but if it does not, the pressure of judicial doubt may force legislative consideration and articulation of the purposes of the parole system.

79. In the last year for which statistics are available, the Board held 14,001 parole hearings. 1960-61 U.S. BD. of PARole ANn. Rep. 3. The report does not make clcar how many of these were revocation hearings although it does state that 1,241 warrants were issued of which 250 were prompted by violations of release conditions rather than the commission of new crimes. Id. at 17.

80. See text at notes 20,21 supra.

81. See Hannah v. Larche, 363 U.S. 420 (1960) (dictum). "Since the requirements of due process frequently vary with the type of proceeding involved ...., we think it is necessary at the outset to ascertain both the nature and function of this Commission." Id. at 440 . See concurring opinion of Mr. Justice Frankfurter. Id. at 487-88.

82. See text at note 37 supra. 